\title{
FACTORS AFFECTING THE USE OF FORENSIC ACCOUNTING SERVICES AN EMPIRICAL STUDY ON INDONESIAN BANKS
}

\author{
Seto Satriyo Bayu Aji \\ Dekar Urumsah \\ Islamic University of Indonesia \\ E-mail: setosatriyo06@gmail.com
}

\author{
ARTICLE INFORMATION \\ Article history: \\ Received July 31, 2015 \\ Revised November 31, 2015 \\ Accepted January 18, 2016

\section{JEL Classifications} \\ M49
}

\section{Key Words:}

Forensic accounting, Internal control systems, Government, Stakeholder, Time budget pressure

DOI:

10.21532/apfj.001.16.01.01.12

\begin{abstract}
The increase in fraud action against financial reports make many people uneasy and considering to use Forensic Accounting Services to prevent and detect fraud. This study aimed to analyse the factors affecting The Intention to Use Forensic Accounting Services in the Banking Industry in Yogyakarta. This research used the survey method and used primary data, which obtained from the population of heads of division and internal auditor staff. This research used SmartPls 2.0 to processed the data with 110 data has been processed.Results of the study find that The Perceived Benefits of Using Forensic Accounting Services affects the Attitudes towards Forensic Accounting Services. Additionally Attitudes toward Forensic Accounting Services, Government Pressure and Internal Control Systems affect the Intention to Use Forensic Accounting Services. Researchers also found that there is no affect of Perceived Risks of Forensic Accounting Services on The Attitudes towards Forensic Accounting Services, as well as Stakeholder Pressure and Time budget Pressure does not affect The Intention to Use Forensic Accounting Services.
\end{abstract}

\section{INTRODUCTION}

Auditing field has been experiencing some major progress and increasingly needed both in government and private agencies in Indonesia. The increase in financial reporting fraud happening recently is one of the affecting factors to use forensic accounting service. This action does not just happen, because frauds are always well-planned that it gets covered from the public (Thoyibatun, 2009), causing an increase in financial reporting fraud in various sectors (Liyanarachchi \& McNamara, 2006). From year to 
year, it seems that financial reporting fraud has become an intriguing topic of conversation in the society.

According to Albrecht (2008), there are two types of fraud; external and internal. External fraud is the one done by people outside an entity or a company, while internal fraud is the one done by a company's staff, managers, and executives. To detect the occurrence of frauds in a company, as stated by Bologna (1993), an internal auditor often needs forensic accounting services to simplify and speed the investigation of fraud action, because the main job of a forensic accountant is to detect frauds occurred in a company.

In the banking industry, it has great probability to occure the fraud therefore it needs the forensic accounting service to uncover cases of the fraud. Such as happened in the case of PT Bank Century, Tbk in 2009. Badan Pemeriksa Keuangan (BPK) as the responsible agent, has found the clarity of Audit Reports Investigation of Bank Century which was the result of the performance of the forensic accountants and investigation of BPK's investigation auditor. As the central bank handling banking industry in Indonesia, Bank Indonesia (2011) has issued a handbill about the anti-fraud strategy implementation for public banks in Indonesia. In providing policies to prevent frauds, Forensic Accounting Services (FAS) follows the policies issued by $\mathrm{BI}$, including the Regulation of Bank Indonesia (2012) about the Implementation of Anti Money Laundry Program and Prevention of Terrorism Funding for Public Banks, and it is important to further set the provision of the implementation. This Handbill regulates the implementation of bank liabilities in preventing banks utilized as money laundry and terrorism funding media as set forth in the Standard Guidelines.

To help the auditors in detecting frauds possible during the investigation, they need to know and understand the types and characteristics of fraud, and the techniques to detect it. One of the techniques that can be used to detect frauds is by searching for red flags, which is an action suspected for causing or potential to cause a fraud. Red flags is a strange situation or different from a normal one (Amrizal,2004).

This research refers to previous studies done by Muthusamy (2010), Liyanarachchi and McNamara (2006) and Thoyibattun (2009). This research is done by digging the perception of the tendency of using forensic accounting services to detect frauds inside the Indonesian national banks and the affecting factors. Those factors include the Perceived Risk of using forensic accounting services, Perceived Benefits of using forensic accounting services, attitudes towards forensic accounting services, Strength of internal control system, shareholders pressure, government pressure, and audit time budget pressure.

The issues to be addressed in this study are put into these research questions:

1. Does the Perceived Benefits and Risks of forensic accounting services positively affect the attitudes towards forensic accounting services? 
2. Does the attitude of using forensic accounting services positively affect the behavioral intention of using forensic accounting services?

3. Does the government, stakeholders and time budget pressure positively affect the behavioral intention of using forensic accounting services?

4. Does the strength of internal control system positively affect the behavioral intention of using forensic accounting services?

The objectives of this research are to confirm the factors affecting the behavioral intention of using forensic accounting services, including the Perceived Benefits of using forensic accounting services, the attitudes towards forensic accounting services, the Perceived Risk of using forensic accounting services, the government pressure, Internal Control System, the stakeholders pressure. This paper is organized as follows. First, a theoretical background and hypothesis development. Next, the research methodology and data collections that will be used in this research. The final part is the discussion of the finding, contribution, implication, limitation, and the suggestion for the future research.

\section{THEORETICAL BACKGROUND AND HYPOTHESES DEVELOPMENT}

Ajzen and Fishben (1980), in Theoretical Planned Behavior (TPB), stated that there was an assumption of people usually behaving in accordance with the consideration of their common sense. Crumbley (2005) said that forensic accounting is the appropriate accounting for legal purposes. In other words, it is an accounting that can survive the fraud during the court proceedings, or in the process of judicial or administrative review. Merriam Webster's Collegiate Dictionary (2003) in Tuanakotta (2010), forensic accounting can be defined as the using of accounting knowledge for legal interests.

Basically, the job description of forensic accountant is to give legal opinions in the litigation. In addition, a forensic accountant is to play a role in legal matters outside the court mandate (non-litigation), for example, in helping to determine the alternatives in resolving the case, to calculate the compensation, and to calculate the impact of contract termination. The main difference between financial audit and forensic audit is the purpose of it; the financial audit aims to extract opinions regarding financial reporting conformity with the applicable financial accounting standards, while forensic audit aims to reveal the frauds occurred in financial reports (Hopwood,2008).

\section{Perceived Benefit and Risk of Using Forensic Accounting Services}

Ikhsan and Ishak (2005) stated that perception was how people saw or interpret events, objects, and each other. People take actions based on their perceptions, ignoring the fact that it might not really reflect the actual reality. In fact, each person has his/ her own perception on what is happening one's description of reality might be far too different with the others'. The formal definition 
of perception is the process where a person chooses, tries, and interprets stimulus into a meaningful and cohesive idea or image.

The perception of the benefits of forensic accounting services is the assessment of the positive result that probably will be obtained with the use of forensic accounting services in the prevention and detection of fraud (Muthusamy, 2010). While the perceived risk of using forensic accounting service is uncertain in decision making to use forensic accounting services to protect and detect of fraud, this can be due to concerns over the risk of negative consequences that will arise with the use of these services (Gewald, Wullenweber, \& Weitzel 2006). The above explanation, these are the following hypotheses are proposed:

H 1 : The perceived benefit of using forensic accounting services affects the attitudes towards forensic accounting services.

H 2 : The perceived risk of using forensic accounting services affects the attitudes towards forensic accounting services.

\section{The Attitudes towards Forensic Accounting}

\section{Services}

The attitudes towards forensic accounting services is an overall evaluation form taken by taking into account all factors and perceptions of benefits and risks that would be obtained by using forensic accounting services (Muthusamy, 2010). An attitude can be defined as the overall evaluation of the person's salient beliefs about whether the outcome of his action will be positive or negative (Quaddus \& Hofmeyer,2007). Thus, the researchers hypothesize the following :

H 3 : The attitudes towards forensic accounting services affects the behavioral intention of using forensic accounting service.

\section{Government Pressure}

The state power on one hand and the company power on the other hand, manage its own controversy. However, there are evidence of government usually being more authoritative in asking and retrieving any information needed from a company (Hofmeyer 2005). Therefore, the researcher hypothesize the following :

H 4 : The government pressure affects the behavioral intention of using forensic accounting service.

\section{Strength of Internal Control System}

Internal control system includes the organizational structure, methods, and measurements coordinated to maintain the organization's assets, to check the accuracy and reliability of accounting data, to encourage efficiency, and to promote compliance on management policies (Mulyadi,2001). The above explanation, this is the following hypothesis is proposed :

H 5 : The strength of internal control system affects the behavioral intention of using forensic accounting service.

\section{Stakeholder Pressure}

The stakeholder has a great influence in making decision. Stakeholders' management expressed the view that the sentiments of the stakeholders could appreciably sway the organization's action. Therefore, stakeholders 
are the one of important element in organizational decision-making ( Hill\& Jones, 1992). Therefore, the researcher hypothesize the following :

H 6 : The stakeholder's pressure affects the behavioral intention of using forensic accounting service.

\section{Time Budget Pressure}

In the audit program there has to be time budget allocation that is set in the early stage of audit, which is the planning stage. Although there have been many researches stating that time budget affects most of the audit quality, whether the time budget is useful for the entire audit process actually depends on the auditor's professionalism. An auditor really considers the time budget because they have to complete his audit work on time (Thoyyibatun,2009). The researchers hypothesize the following :
H 7 : Time budget pressure affects the behavioral intention of using forensic accounting service.

In the later research done by Muthusamy (2010), studying the attitudes towards forensic accounting services to detect and prevent frauds in major companies in Malaysia, the conclusion was that $45,5 \%$ of respondents had the intention to use forensic accounting services. Similar result came from the research done by Liyanarachchi and McNamara (2006), it was concluded that the pressure of time budget affected the performance of an auditor. The research done by Peterson and Zikmund (2004), stated that by using Forensic Accounting Services, frauds can be prevented. Considering these results from the previous studies above, the researchers have made the research model as presented in figure 1 that will be proposed research model.

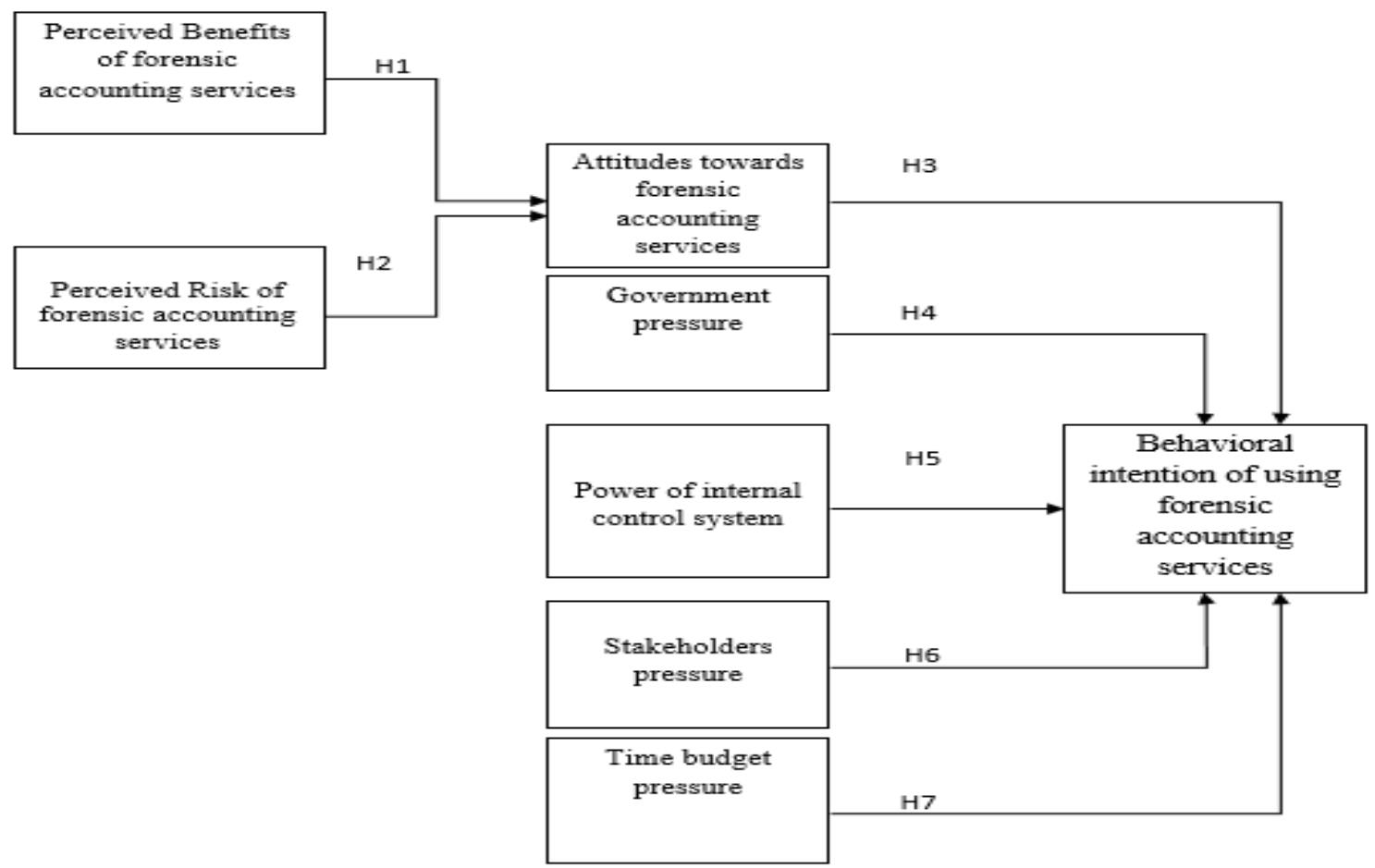

Figure 1. Proposed Reseach Model 


\section{RESEARCH METHODS}

\section{Research Method and Data Collection}

This research is done based on quantitive approach by using survey method. Survey method is a technique of data collection done by giving questions to individual respondents. The population used in this research is the internal auditor staff of National Banks located in Yogyakarta. In this research, the samples were the head of divisions or an internal auditor staff in National Banks located in Yogyakarta. The data used in this research were directly obtained from the survey done by the researchers, by giving out questionnaires to the internal auditor staff in Indonesian. Exploratory and confirmatory factor analysis were used in this research assessed by examining validity and composite realibility with Partial Least Square (SmartPLS 2.0).

\section{Variable Definition and Measurement}

To measure the indicator of the variables in this research, the Likert scale with interval 1-6 was used, from Strongly Disagree to Strongly Agree. Next, the attributes and the indicators are put into the questionnaire by giving scores for each item in the questions asked as presented in Table 1 bellow :

\section{Table 1. Variable Definition and Measurement}

\begin{tabular}{|c|c|c|c|}
\hline Variable & Variable Definition & Measurement & References \\
\hline $\begin{array}{l}\text { The perceptions } \\
\text { of benefit of } \\
\text { using forensic } \\
\text { a c c o unting } \\
\text { services }\end{array}$ & $\begin{array}{l}\text { The Perceived Benefits of forensic } \\
\text { accounting services is an assessment of } \\
\text { a positive result possible to retrieve from } \\
\text { using forensic accounting services in } \\
\text { preventing and detecting frauds. }\end{array}$ & 13 Items & $\begin{array}{l}\text { Muthusamy,2010; } \\
\text { Peterson \& } \\
\text { Zikmund,2004 }\end{array}$ \\
\hline $\begin{array}{l}\text { The Perceived } \\
\text { Risk of forensic } \\
\text { a c c o unt ing } \\
\text { services }\end{array}$ & $\begin{array}{l}\text { The Perceived Risk of forensic accounting } \\
\text { services is an uncertainty in making } \\
\text { the decision to use forensic accounting } \\
\text { services in preventing and detecting } \\
\text { frauds due to concerns of negative } \\
\text { consequences caused by the service. }\end{array}$ & 6 Items & $\begin{array}{c}\text { Muthusamy,2010; } \\
\text { Gewald, } \\
\text { Wullenweber, \& } \\
\text { Weitzel, } 2006\end{array}$ \\
\hline $\begin{array}{l}\text { The attitudes } \\
\text { of forensic } \\
\text { accounting } \\
\text { services } \\
\text { Government } \\
\text { Pressure }\end{array}$ & $\begin{array}{l}\text { The attitudes of forensic accounting } \\
\text { data is a form of overall evaluation } \\
\text { performed by calculating all factors and } \\
\text { the Perceived Benefits and risk of using } \\
\text { forensic accounting services. }\end{array}$ & 10 Items & $\begin{array}{c}\text { Quaddus \& } \\
\text { Hofmeyer,2007; } \\
\text { Muthusamy,2010 }\end{array}$ \\
\hline $\begin{array}{l}\text { Strength of } \\
\text { internal control } \\
\text { system }\end{array}$ & $\begin{array}{l}\text { Strength of internal control system is } \\
\text { a power owned by the internal control } \\
\text { system of an entity to detect and prevent } \\
\text { frauds }\end{array}$ & 16 Items & Mulyadi, 2001 \\
\hline
\end{tabular}




\begin{tabular}{|c|c|c|c|}
\hline $\begin{array}{l}\text { Stakeholder } \\
\text { Pressure }\end{array}$ & $\begin{array}{l}\text { Stakeholder Pressure refers to the } \\
\text { demands made by the stakeholders to } \\
\text { the company based on their economic } \\
\text { interests. }\end{array}$ & 5 Items & $\begin{array}{l}\text { Hofmeyer,2005; } \\
\text { Hill \& Jones, } 1992\end{array}$ \\
\hline $\begin{array}{l}\text { Time budget } \\
\text { Pressure }\end{array}$ & $\begin{array}{l}\text { Time budget pressure is the time allocated } \\
\text { for an internal auditor to complete his/her } \\
\text { audit tasks that he/she needs help from } \\
\text { forensic accounting services to detect } \\
\text { and prevent frauds, to simplify his/her } \\
\text { internal audit tasks. }\end{array}$ & 9 Items & $\begin{array}{c}\text { Thoyyibatun, } \\
2009\end{array}$ \\
\hline $\begin{array}{l}\text { Intention of } \\
\text { Using Forensic } \\
\text { Acc ounting } \\
\text { Services }\end{array}$ & $\begin{array}{l}\text { Intention of using forensic accounting } \\
\text { services is the company's willingness } \\
\text { to use forensic accounting services in } \\
\text { preventing and detecting frauds after } \\
\text { considering several factors affecting } \\
\text { the decision making of using forensic } \\
\text { accounting services. }\end{array}$ & 3 Items & Muthusamy, 2010 \\
\hline
\end{tabular}

\section{DATA ANALYSIS AND DISCUSSION}

The data that used in this research were directly obtained from the survey done by the researchers, by giving out questionnaires to the internal auditor staff in National Banks located in Yogyakarta. Exploratory and confirmatory factor analysis were used in this research assessed by examining validity and composite realibility with Partial Least Square (SmartPLS 2.0) which are, Measurement Evaluation with Validity Test and Realibility Test. While to assessing Inner Model, reseachers used R-Square and T-Statisik Test.

\section{Measurement Evaluation (Outer Model) Validity Test}

The validity test in this research used the convergent validity dan discriminant validity tests. Convergent validity is a measurement model with reflective indicators assessed based on the correlation between the item score or component score with construct score calculated using PLS. The invidividual reflective measurement is high if it correlates for more that 0,5 (with significance of 0,05 and T statistic $>1,64)$.

While the test using discriminant validity is done by comparing the value of square root of average variance extracted (AVE) of each construct with correlation between constructs in the model. If the AVE quadran of each construct is bigger than the value of correlation between constructs, then it has a good discriminant validity score as shown on Table 2 bellow. 
Table 2 Initial Item Loadings and AVE

\begin{tabular}{|c|c|c|c|c|}
\hline Variable & Indicator & Code & Loading & AVE \\
\hline \multirow{6}{*}{$\begin{array}{l}\text { Perceived } \\
\text { Benefits of } \\
\text { Forensic } \\
\text { Accounting } \\
\text { Services } \\
\text { (FAS) }\end{array}$} & Preventing frauds & PMJ3 & 0.723 & \multirow{6}{*}{0.544} \\
\hline & Returning assets and refunding cash & PMJ4 & 0.744 & \\
\hline & Improving company's image & PMJ5 & 0.720 & \\
\hline & Detecting and preventing frauds & PMJ11 & 0.676 & \\
\hline & FAS affecting positively & PMJ12 & 0.676 & \\
\hline & Benefits being bigger than the risks & PMJ13 & 0.749 & \\
\hline \multirow{4}{*}{$\begin{array}{c}\text { Perceived } \\
\text { Risk of Using } \\
\text { FAS }\end{array}$} & Understand the risk of using FAS & PRJ1 & 0.725 & \multirow{4}{*}{0.558} \\
\hline & High cost of FAS & PRJ2 & 0.653 & \\
\hline & Sign that the company is having issues & PRJ3 & 0.726 & \\
\hline & Limiting staff decision making & PRJ6 & 0.647 & \\
\hline \multirow{4}{*}{$\begin{array}{c}\text { Attitudes } \\
\text { towards FAS }\end{array}$} & Affecting company's image & STJ2 & 0.733 & \multirow{4}{*}{0.607} \\
\hline & Affecting staff's moral & STJ3 & 0.728 & \\
\hline & Affecting productivity and efficiency & STJ4 & 0.722 & \\
\hline & Higher risk of frauds & STJ10 & 0.733 & \\
\hline \multirow{3}{*}{$\begin{array}{l}\text { Government } \\
\text { Pressure }\end{array}$} & $\begin{array}{l}\text { Government regulation promotes } \\
\text { accountability }\end{array}$ & TP1 & 0.662 & \multirow{3}{*}{0.681} \\
\hline & Government oblige the use of FAS & TP3 & 0.677 & \\
\hline & Government demand company to use FAS & TP4 & 0.711 & \\
\hline \multirow{6}{*}{$\begin{array}{l}\text { Strength } \\
\text { of internal } \\
\text { control } \\
\text { system }\end{array}$} & Prioritize company's interest & SPI5 & 0.772 & \multirow{6}{*}{0.735} \\
\hline & Unstandardized & SPI6 & 0.788 & \\
\hline & Staff controlling the cost & SPI7 & 0.779 & \\
\hline & Tasked with stratified authorities & SPI12 & 0.772 & \\
\hline & Risk identification, analysis, and control & SPI13 & 0.788 & \\
\hline & Communication and information delivery & SPI14 & 0.779 & \\
\hline \multirow{3}{*}{$\begin{array}{l}\text { Stakeholder } \\
\text { Pressure }\end{array}$} & Shareholders demand to use FAS & TS1 & 0.787 & \multirow{3}{*}{0.750} \\
\hline & Lenders oblige to use FAS & TS2 & 0.837 & \\
\hline & Customers must use FAS & TS3 & 0.853 & \\
\hline \multirow{4}{*}{$\begin{array}{l}\text { Time budget } \\
\text { Pressure }\end{array}$} & Completing the task on time & TAW2 & 0.665 & \multirow{4}{*}{0.577} \\
\hline & Time budget causing audit termination & TAW4 & 0.799 & \\
\hline & Lower the effectiveness and efficiency & TAW5 & 0.753 & \\
\hline & Audit process affecting its quality & TAW9 & 0.665 & \\
\hline \multirow{3}{*}{$\begin{array}{l}\text { Intention to } \\
\text { Use FAS }\end{array}$} & Company is willing to use FAS & NMJ1 & 0.745 & \multirow{3}{*}{0.547} \\
\hline & Company chooses to use FAS & NMJ2 & 0.742 & \\
\hline & Company will use FAS & NMJ3 & 0.716 & \\
\hline
\end{tabular}

Source: Data Analyzed 
As presented on table 2, explained that the AVE of the Perceived Benefits of Using FAS construct (PMJ), the Perceived Risk of Using FAS (PRJ), The Attitudes towards Using FAS (STJ), Government Pressure (TP), Strength of internal control system (SPI), Stakeholders Pressure (TS), Time budget Pressure (TAW), and Intention of Using FAS (NMJ) are below 0,5 . Some numbers of the loading factor showed similarity; below 0,5. Later in table 4.5 all constructs should produce the values of AVE and loading factor of more than 0,5 by putting several indicators in each construct still producing below 0,5. After comparing the two tables, the indicators used in this research are valid or have met the convergent validity.

\section{Reliability Test}

Composite reliability can be used to measure reliability from the existed construct data. Constructs are considered reliable if the value of composite reliability is above 0,70 . Below is the result of construct calculation summarized in internal composite reliability and correlation among constructs illustrated on Table 3.
As showed at Table 3 above, the value of composite reliability for all constructs is above 0,70 , indicating that all constructs on the estimated model met the criteria of discriminant validity. The value of lowest composite reliability is of 0,716 for the Government Pressure construct (TP).

\section{Assessing Inner Model or Research Result Structural Model}

After the estimated model meeting the criteria of the outer model, the next step to be done is the structural model test (inner model).

\section{R-Square $\left(\mathbf{R}^{2}\right)$ test}

$\mathrm{R}$-Square $\left(\mathrm{R}^{2}\right)$ test is an explanatory powers of the model were assessed by calculating the coefficient of determination $\left(\mathrm{R}^{2}\right)$ (Santosa, Wei \& Chan, 2005) as illustrated on Table 4.

Table 4. $R^{2}$ Value

\begin{tabular}{|l|c|}
\hline \multicolumn{1}{|c|}{ Construct } & R Square \\
\hline Attitudes towards FAS & 0,886 \\
\hline Intention to Use FAS & 0,328 \\
\hline
\end{tabular}

Source: Data Analyzed

Table 3. Internal Composite Reliability and Correlation among Constructs

\begin{tabular}{|c|c|c|c|c|c|c|c|c|c|}
\hline & CR & PMJ & PRJ & STJ & TP & SPI & TS & TAW & NMJ \\
\hline PMJ & 0.878 & $\mathbf{0 . 7 3 8}$ & & & & & & & \\
\hline PRJ & 0.835 & 0.433 & $\mathbf{0 . 7 4 7}$ & & & & & & \\
\hline STJ & 0.860 & 0.941 & 0.380 & $\mathbf{0 . 7 7 9}$ & & & & & \\
\hline TP & 0.716 & 0.575 & 0.275 & 0.670 & $\mathbf{0 . 7 4 7}$ & & & & \\
\hline SPI & 0.943 & 0.862 & 0.252 & 0.809 & 0.650 & $\mathbf{0 . 8 5 7}$ & & & \\
\hline TS & 0.899 & 0.851 & 0.497 & 0.782 & 0.309 & 0.470 & $\mathbf{0 . 8 6 6}$ & & \\
\hline TAW & 0.842 & 0.791 & 0.548 & 0.743 & 0.268 & 0.441 & 0.920 & $\mathbf{0 . 7 5 9}$ & \\
\hline NMJ & 0.784 & 0.464 & 0.513 & 0.441 & 0.506 & 0.479 & 0.320 & 0.304 & $\mathbf{0 . 7 4 0}$ \\
\hline
\end{tabular}

Source: Data Analyzed 
As Table 4 showed above the Attitudes towards Forensic Accounting Services value of 0,886 (STJ), indicating that the Perceived Benefits of Using FAS (PMJ) and the Perceived Risk of Using FAS (PRJ) explained the variance of $88,6 \%$. R-Square value also occurred in Intention of Using FAS (NMJ) affected by all other constructs, which is of 0,328 , indicating the Government Pressure (TP), Strength of internal control system (SPI), Stakeholders Pressure (TS), and Time budget Pressure (TAW) explained the NMJ variance of $32,8 \%$.

\section{T-Statistic Test}

Based on the analyzed data, the result to be used for T-Statistic test for testing the hypotheses is shown in Table 5. At this part, the analysis result is interpreted and discussed with explanation. The first part is delivering interpretation and presenting discussion of the antecedent factors of unethical use of computer and the second part is presenting the discussion of moderation effect result from the demographic factor of this research.

The hypotheses test is done by considering the $t$-value and path coefficient $(\beta)$. As shown in table 5, four hypotheses are supported while the other three are not. After this evaluation, the next part will be about delivering interpretation and presenting discussion of the research result as showed on Table 5.

Table 5 Hypothesis Conclusion (T-Statistic)

\begin{tabular}{|c|c|c|c|c|}
\hline \multicolumn{1}{|c}{ Hypothesis } & \multicolumn{1}{c}{ Relationship } & \multicolumn{1}{c|}{ B } & t-Value & Result \\
\hline H1 & PMJ -> STJ & 0.955 & 55.525 & Supported \\
\hline H2 & PRJ -> STJ & -0.034 & 1.024 & Not Supported \\
\hline H3 & STJ -> NMJ & 0.453 & 1.815 & Supported \\
\hline H4 & TP -> NMJ & 0.454 & 2.805 & Supported \\
\hline H5 & SPI -> NMJ & 0.382 & 2.355 & Supported \\
\hline H6 & TS -> NMJ & 0.209 & 0.747 & Not Supported \\
\hline H7 & TAW -> NMJ & 0.158 & 0.580 & Not Supported \\
\hline
\end{tabular}

Source: Data Analyzed

\section{The Perceived Benefits of FAS to the Attitudes towards FAS (H1)}

The data analysis showed that the Perceived Benefits of FAS affect the attitudes towards FAS. This finding indicated that with the perception from an organization about the benefit of FAS, its attitudes towards FAS would be more open, and it likely would use FAS is there happen frauds in that organization. The result of this research supports the one has made by Muthusamy (2010) and it is accordance with the statement of Peterson and Zikmund (2004) which found that using the forensic accounting services may prevent the occurrence of the fraud.

\section{Perceived Risk of FAS to the Attitudes of FAS (H2)}

The data analysis of this research showed that the Perceived Risk of FAS does not affect the attitudes towards FAS. This indicates that the Perceived Risk from an organization of using FAS does not affect its attitudes towards using FAS. Meaning, although an organization 
understands the risks of using FAS, this does not subdue its attitudes towards using FAS because the benefit of FAS might be even far bigger than the feared consequences. Additionally, the existence of government regulation or authorities (OJK) encourages an entity not to worry about the possible risks anymore, to comply more to the government regulation or in this case, OJK's. This makes the role of OJK's policies is crucial in making an entity ignore the Perceived Risk of using FAS. This research is similar with the previous one done by Heijden, Verhagen \& Creemer (2003), stated that there are negative relations between the perceived risk of using FAS with the attitude towards FAS.

\section{Attitudes towards FAS to the Intention of Using FAS (H3)}

Based on the analysis in this research, the attitudes towards FAS affect the intention of using FAS that it can be concluded that the attitudes of using FAS will encourage the use of FAS when frauds occur. This is good because the positive attitudes towards using FAS will bring forward forensic accounting services. The result of this research pointed the same result with Muthusamy (2010), stated that the attitude towards using FAS affects the intention of using FAS.

\section{Government Pressure to the Intention of Using FAS (H4)}

The analysis of this research showed that the existence of government pressure affects the intention of using FAS. The government pressure, as a regulator, affects the intention of an organization to use FAS, because one has to comply with the regulations made by the government and to avoid violating them. That result supports Hofmeyer (2005), which found that there is significant influence from the government's pressure towards the awareness of using FAS.

\section{Strength of internal control system to the Intention of Using FAS (H5)}

Based on the analysis in this research, the strength of internal control system affects the intention of using FAS. With the existence of the strength of internal control system, the intention of using FAS would get higher because it can support the internal control system to prevent and discover frauds occur in an organization. That result has similarity with Hofmeyer (2005), which found that strength of internal control system significant influence the intention of using FAS.

\section{Stakeholder Pressure to the Intention of Using FAS (H6)}

The data analysis showed that the stakeholder pressure does not affect the intention of using FAS. Stakeholders as the people in control do not want any fraud to happen in their organization. This pressures the organization to use FAS if a fraud has happened, though that is not the key aspect affecting the use of FAS because there are several other important ones, one of them is the estimated high cost of using FAS that the management would try to find the fraud themselves and try to prevent it employing the internal auditor available inside the organization. The result of this research 
doesn't fit with Muthusamy (2010), stated that the stakeholder pressure affects the intention of using FAS.

\section{Time budget Pressure to the Intention of Using FAS (H7)}

Based on the analysis of this research, the time budget pressure affects the intention of using FAS. In an audit process, a time budget must be set first regarding when it is supposed to thoroughly done. This also applies to when a fraud happens in an organization; it needs to be discovered immediately. The limited time provided would make an internal auditor feel under pressure that the intention of using FAS would emerge to speed and simplify the fraud auditing process. However, not all organization would immediately decide to use FAS; a lot of them are not affected by time budget pressure and prioritize on finding the fraud even if it would take longer than if they use FAS. One of the key factors of this reluctance is the high cost of using FAS. The result of this research pointed the same result with Thoyyibattun (2009), stated that time budget pressure affects the intention of using FAS

\section{CONCLUSION}

This research aims to understand the effect of relations of the Attitudes towards Forensic Accounting Services, Government Pressure, Strength of internal control system, Stakeholder Pressure, and Time budget Pressure to the Intention of Using Forensic Accounting Services. Additionally, it also aims to find out what are the influences of the Perceived Benefits of Using Forensic Accounting Services and the
Perceived Risk of Using Forensic Accounting Services to the Attitudes towards Using Forensic Accounting Services. The research results are listed below:

1. The Perceived Benefits of Using Forensic Accounting Services is proven to be affecting the Attitudes towards Forensic Accounting Services. Supported by the obtained data, the result can then be used to make decisions in the future, and subsequently will affect the Attitudes towards Forensic Accounting Services.

2. The Perceived Risk of Using Forensic Accounting Services does not evidently affect the Attitudes towards Forensic Accounting Services and this is supported by the data obtained. The result showed that the Perceived Risk of Using FAS does not affect the decision making in the future and consequently will not subdue the Attitudes towards Forensic Accounting Services.

3. The Attitudes towards FAS is proven to positively affect the Intention of Using FAS, and this is supported by the data of this research, so the result can be used for a reference in decision making in the future, and subsequently raise the Intention of Using Forensic Accounting Services.

4. The researchers found that the government pressure positively affects the intention of using FAS and this is supported by the data obtained. The stronger the pressure coming from the government, the more urgent the intention of using FAS. 
5. The Strength of internal control system does evidently affect the Intention of Using Forensic Accounting Services and this is supported by the data of this research. The result can be used for a future reference in decision making and raise the Intention of Using Forensic Accounting Services

6. This research states that the Stakeholder Pressure does not affect the Intention of Using FAS and this is supported by the data obtained. The result can later be used as a reference in decision making which will eventually raise the Intention of Using FAS.

7. Time budget Pressure does not affect the Intention of Using Forensic Accounting Services and this is supported by the data obtained. The result can later be used as a reference in decision making which will eventually raise the Intention of Using FAS.

\section{Research Implication}

This research can provide knowledge for the Forensic Accounting Practitioner to help detect financial reporting fraud in their companies or entities. It cannot be denied that the internal auditor needs forensic accounting data services to make the tasks of detection easier. Hopefully, this research is beneficial for the society by providing new insights about the tendency of using forensic accounting services in detecting financial reporting fraud. For the academics, this research hopefully can emerge as one reliable information source and reference, especially in the accounting field, to be used in future relevant researches.

\section{Research Limitation and Suggestion}

The researchers faced several limitation in completing this study, therefore there are some suggestions below which hopefully can assist fellow researcherss in the future.

\section{Limitation}

Despite of the presented research results, the researchers thought that this research has its own limitations and weaknesses. We have worked our best to minimize both the controlable limitations and the uncontrolable ones as listed below:

1. The data collection of this research still used the questionnaire technique with many questions on the sheet, which made the data obtained was rather difficult to analyze. Additionally, the scale used in the data is the rating one which did not provide the actual measurement needed from the respondents.

2. The language in the questionnaire was rather too complicated to understand that many of the respondents felt a little lost with several question item in the sheet.

3. The result made the analysis on the research objects limited only to banking industry, which in this case only applied to National Banks located in Yogyakarta, that it causes result and conclusion differences with different and additional objects. 
4. The number of respondents is limited because this research only focused on the heads of division and internal audit staff. This is because the question item in the questionnaire can probably be understood only by the heads of division and internal audit staff.

\section{Suggestions}

This research has its own weaknesses; therefore the researchers offer some suggestion that can hopefully assist fellow researchers in the future:

1. Simplify and improve the language used in the questionnaire for the respondents to understand it more easily.

2. Increase the number of respondents to make the research more comprehensive.

3. Broaden the objects of research to other industries or organizations to develop more.

4. Develop and add some more potential factors to influence the Intention of Using Forensic Accounting Services and to input added value to future researches.

The aforementioned obstacles have been minimized by creating a well-planned and interesting questionnaire and simplifying the language used in it. In efforts to prevent and resolve frauds, the management is ordered to use forensic accounting services as one of the solutions, and hopefully it can help bring forward the forensic accounting field in the future. However, efforts of improvement still need to be reinforced, especially for the researchers interested to continue further on this research.

\section{REFERENCES}

ACFE 2000. “Fraud Examiners Manual, Third Edition

AICPA Forensic and Litigation Services Committee and Fraud Task Force 2004 Forensic Services, Audits, and Corporate Governance: Bridging the Gap, American Institute of Certified Public Accountants, Inc., New York.

AICPA Forensic and Litigation Services Committee 2006, Forensic Procedures and Specialists: Useful Tools and Techniques, American Institute of Certified Public Accountants, Inc., New York.

Albrecht, W. S \& Albrecht, C.C 2003, Root Out Financial Deception, Journal of Accountancy 193(4): 30-34.

Albrecht, W. S \& Albrecht, C.C 2008, Current Trends in Fraud and Its Detection, Information Security Journal: A Global Perspective 17(1): 2-12.

Ajzen, I. \& M. Fishbein 1980, Understanding Attitudes and Predicting Social Behavior, Englewood Cliffs, NJ: Prentice-Hall.

Ajzen, I. \& T. J. Madden 1986, Prediction of Goal-Directed Behaviour : Attitudes, Intentions and Perceived Behavioural Control, Journal of Experimental Social Psychology 22: 453-474.

American Institute of Certified Public Accountants (AICPA) 2004, Forensic 
services, audits, and corporate governance: Bridging the gap (Discussion memorandum), New York: Author.

Amrizal 2004, "Pencegahan dan Pendeteksian Kecurangan oleh Internal Auditor." Viewed 20 Agustus 2014.

Apostolou, N 2012, The Value of Risk Assessment: Evidence from Recent Survey.

Bank Indonesia 2011, "Surat Edaran, Perihal

: Penerapan Strategi Anti Fraud bagi Bank Umum”

Bank Indonesia 2012, "Peraturan Bank Indonesia Nomor 14/27/PBI/2012: Penerapan Program Anti Pencucian Uang dan Pencegahan Pendanaan Terorisme."

Bank Indonesia 2013, "Surat Edaran Nomor 15/21/DPNP, Perihal : Penerapan Program Anti Pencucian Uang dan Pencegahan Pendanaan Terorisme."

Bologna, G. J. \& Lindquist.R 1995, Fraud Auditing and Forensic Accounting, JohnWilley \& Sons: New York.

Crumbley, D. L 2003, Journal of Forensic Accounting.

Crumbley, D. L 2001, Forensic Accounting: Older Than You Think, Journal of Forensic Accounting II(2): 181-202.

Crumbley, D. L \& Apostolou, N 2002. Forensic Accounting: A New Growth Area in Accounting, The Ohio CPA Journal 61(3): 16-20.
Crumbley, D. L \& Apostolou, N 2005. The Expanding Role of The Forensic Accountant, The Forensic Examiner 14(3): 39-43.

Dadang Sadeli, Nelly Nur Apandi, Rizkia, M 2013, Pengaruh Audit Tenure Terhadap Fraudulent Financial Reporting Dengan Pendekatan Akrual Diskresioner (Studi Pada Perusahaan Non Lembaga Keuangan Yang Listing Di Bursa Efek Indonesia Periode 2009-2011), JRAK (Jurnal Riset Akuntansi Dan Keuangan), Volume 1, nomor 1

DeZoort, F.T 1998. Time Pressure Research in Auditing: Implications for Practice, The Auditor Report 22.

Fornell, C. \& Larcker, D.F 1981, Evaluating structural equation models with unobservable variables and measurement error, Journal of MarketingResearch 18(1): 39-50.

Gewald, H, Wullenweber, K. \& Weitzel, T 2006, The influence of perceived risks on banking managers' intention to outsource business processes: A study of the German banking and finance industry. Journal of Electronic Commerce Research, 7(2), 7894

Ghozali 2008, ”Structural Equation Modeling Metode Alternatif dengan Partial Least Square. "Semarang : Badan Penerbit Universitas Diponegoro.

Heijden, H., Verhagen, T., \& Creemers, M 2003, Understanding online purchase intentions: contributions from technology 
and trust perspectives,European Journal of Information Systems, 12(1): 41-48.

Hill, C. W. L., \& Jones, T. M 1992, StakeholderAgency Theory. Journal of Management Studies, 29(2), 131-154.

Hofmeyer, G. D 2005, An investigation of the factors that influence the intention to adopt business to business (B2B) trading exchanges in small business in Western Australia. Doctoral dissertation, Curtin University of Technology, Western Australia.

Hopwood, W. S., Leiner, J., \& Young, G. R. 2008, Forensic Accounting, McGrawHill/Irwin, New York.

Ikhsan Arfan \& Muhammad Ishak 2005, Akuntansi Keperilakuan, Salemba Empat, Jakarta.

Liyanarachchi, G. A. \& McNamara, S. M 2006, New Zealand Auditors are Under Pressure to Meet Time Budgets, Forthcoming article in the Chartered Accountants Journal of New Zealand.

Mulyadi 2001, Sistem Akuntansi, Jakarta: Salemba Empat

Muthusamy, G 2010, Organizational Intention to Use Forensic Accounting Services for Fraud Detection and Prevention by Large Malaysian Companies, Oxford Business \& Economics Conference Program, Oxford, June 28-29, 2010

Nor, Mohd Nazli Moh 2010, Auditor's Perception of Time Budget Pressure and Reduced Audit Quality Practices :

\section{A Prelimimanry Study From Malaysian} Context, Faculty of Business and Law, Edith Cowan University, Australia.

Peterson, B. K. \& Zikmund, P.E 2004, 10 Truths you need to know about fraud, Strategic Finance. 85(11): 29-34.

Quaddus, M., \& Hofmeyer, G 2007, An investigation into the factors influencing the adoption of B2B trading exchanges in small business. European Journal of Information Systems, 16(2), 202-215.

Santosa, P. I., Wei, K. K. \& Chan, H. C 2005, User involvement and user satisfaction with information-seeking activity. European Journal of Information Systems, 14(4), 361-370.

Siti Thoyibatun 2009, Faktor- faktor yang Berpengaruh Terhadap Perilaku Tidak Etis dan Kecenderungan Kecurangan Akuntansi Serta Akibatnya Terhadap Kinerja Organisasi, Ekuitas: Jurnal Ekonomi dan Keuangan, Volume 16, Nomor 2, Juni $2012: 245-260$

Oyier, O.E 2013, The Impact Of Forensic Accounting Services on Fraud Detection And Prevention Among Commercial Banks In Kenya, School Of Business University Of Nairobi.

Theodorus Tuanakotta 2007, Akuntansi Forensik dan Audit Investigasi, Jakarta :Lembaga Penerbit Fakultas Ekonomi Universitas Indonesia.

Wilopo 2006, Analisis Faktor-faktor yang Berpengaruh Terhadap Kecenderungan 
Terjadinya Kecurangan Akuntansi : Studi pada Perusahaan BUMN dan Publik di Indonesia, Jakarta : Media Riset Akuntansi, auditing, danInformasi.

Zikmund, P. E \& O'Reilly-Allen.M 2007, I'm an Auditor, Darn It, Not an Investigator, right?, Pennsylvania CPA Journal 78(3): 28-31. 